\title{
Insecurity, Dispossession, Depletion: Women's Experiences of Post-War Development in Myanmar
}

\author{
Jenny Hedström ${ }^{1,2} \cdot$ Elisabeth Olivius $^{1}$ (i)
}

Published online: 26 March 2020

(c) The Author(s) 2020

\begin{abstract}
This article explores the gendered dynamics of Myanmar's post-war economic reforms through an analysis of women's experiences of development in Kayah (Karenni) state. In Myanmar, ceasefires and a reduction of armed violence combined with state-driven economic liberalization reforms are conditioned by, but also contribute to remake, gendered relations of power, privilege and marginalization. While new land legislation and development projects have contributed to loss of land and livelihoods among rural populations in general, our study demonstrates that women living in conflict-affected border areas are disproportionally affected. Drawing on interviews and participant observation, we show how this is directly related to an overarching gendered political economy defined by legacies of conflict, discrimination and uneven processes of development, which positions women as particularly vulnerable to new forms of insecurity, dispossession and depletion generated by post-war economic transformations. We argue that the political and economic legacies of war in the state has produced a gendered division of labor that positions women as responsible for unpaid and underpaid informal and social reproductive labor, weakens women's access to land, and results in physical, material, and emotional depletion. Through this focus, our study adds to research on development and economic restructuring in post-war contexts in general, and to emergent scholarship on Myanmar's economic reforms in particular.
\end{abstract}

Keywords Post-war economic development - Gender · Feminist political economy · Informal labor $\cdot$ Land rights $\cdot$ Myanmar $\cdot$ Kayah/Karenni state

\section{Résumé}

Cet article explore la dynamique de genre des réformes économiques de l'aprèsguerre au Myanmar à travers une analyse des expériences de développement des

Elisabeth Olivius

Elisabeth.olivius@umu.se

Jenny Hedström

j.e.hedstrom@gmail.com

1 Umeå University, Umeå, Sweden

2 Örebro University, Örebro, Sweden 
femmes dans l'État de Kayah (Karenni). Au Myanmar, les cessez-le-feu et la réduction de la violence armée, combinés à des réformes de libéralisation économique impulsées par l'État, sont conditionnés par les relations de pouvoir fondées sur le sexe, par les privilèges et la marginalisation, mais ils y contribuent également. Alors que la nouvelle législation foncière et les projets de développement ont contribué de façon générale à la perte de terres et de moyens de subsistance de la part des populations rurales, notre étude montre que les femmes vivant dans les zones frontalières touchées par les conflits sont affectées de manière disproportionnée. À partir d'entretiens et d'observations émanant des participants, nous montrons comment cela s'inscrit directement dans le cadre d'une économie politique globale basée sur le genre, qui tire son héritage du conflit, de la discrimination et des processus de développement inégaux, et qui rend les femmes particulièrement vulnérables aux nouvelles formes d'insécurité, d'expropriation et d'appauvrissement produites par les transformations économiques d'après-guerre. Nous soutenons que les héritages politiques et économiques de la guerre dans l'État ont produit une division du travail fondée sur le sexe qui rend les femmes responsables du travail informel reproductif et social, non rémunéré et sous-payé, qui affaiblit l'accès des femmes à la terre et qui se traduit par un appauvrissement physique, matériel et émotionnel. Grâce à cet objectif, notre étude vient s'ajouter à l'ensemble de la recherche sur le développement et la restructuration économique dans les contextes d'après-guerre en général, et à la connaissance émergente sur les réformes économiques du Myanmar en particulier.

\section{Introduction}

In Myanmar, ceasefires and a reduction in armed violence combined with state-driven economic liberalization reforms have unleashed far-reaching processes of transformation in the country's conflict-affected, minority-populated border areas. An upsurge in state-led development initiatives and foreign investment, new land laws, and a general strengthening of state control in previously rebel-held territories are fundamentally reshaping social, political and economic relationships in these areas (Bello 2018; Burke et al. 2017; Brenner 2017; Jones 2014). However, research examining these processes of change does not attend to the ways in which they are conditioned by, but also contribute to remake, gendered relations of power, privilege and marginalization. Addressing this gap, we explore the gendered dynamics of Myanmar's post-war economic reforms through an analysis of women's experiences of development in Kayah (Karenni) state. ${ }^{1}$ Through this focus, our study adds to research on gender, development and economic restructuring in post-war contexts in general, and to emergent scholarship on Myanmar's economic reforms in particular. Our research illustrates how ongoing transitional processes intersect with existing gendered divisions of labor, land and

\footnotetext{
${ }^{1}$ Karenni state became Kayah state in 1952 , but the name Kayah has not been widely used by people active in civil society, or armed or other resistance organizations, many of which still use the name Karenni to talk about the state and the collective of people living there. In this paper, for reasons of simplicity, we use the name Kayah to refer to the state, except when quoting respondents using the name Karenni.
} 
exclusion in conflict-affected areas of the country. Building on interviews, focus group discussions and participatory observation, and employing a feminist political economy framework, we address Cynthia Enloe's (1990) now classic question-where are the women? In other words, where are the women in the complex entanglements of development, state building, and legacies of war in Kayah state? How are they experiencing changes brought about by ceasefire deals and development interventions, and what does this mean for women's physical, emotional, and material wellbeing? Addressing these questions are key to a fuller understanding of the transformations that are unfolding in Myanmar's conflict-affected borderlands.

Our results demonstrate that gendered insecurity is reproduced through land formalization; through development interventions such as infrastructure, energy and agribusiness projects; and through state consolidation of power in ethnic minority areas (see Scurrah et al. 2015; Woods 2011, 2016b). While new land legislation and development projects have contributed to loss of land and livelihoods among rural populations in general, we argue that women living in conflict-affected border areas are disproportionally affected by these changes (Agatha Ma and Kusakabe 2015; Mi Thang Sorn Poine 2018). In our analysis, we show how this is directly related to an overarching gendered political economy defined by legacies of conflict, discrimination and uneven processes of development. This positions women as particularly vulnerable to new forms of insecurity, dispossession and depletion generated by post-war economic transformations. Notably, women are overrepresented in the informal and subsistence economy; women's land tenure is highly precarious; and the lack of social provisioning by the state results in women shouldering the full burden of intergenerational and community reproduction (Hedström 2017; Faxon 2017; Gender Equality Network 2015; Belak 2002).

The article is structured as follows. We begin by providing a brief overview of the history of armed conflict, ceasefires, and development processes in Kayah state. We conceptualize state-led, post-war development as a case of illiberal peacebuilding, emphasizing the links between development, peacebuilding, and state building. Turning next to an outline of the analytical framework, we draw particular attention to gendered divisions of labor during and after war; the gender dynamics of formal and informal labor; and physical, material, and emotional depletion and harm in post-war development. The materials and methods that underpin our analysis are then described. Following with our analysis, we illustrate how political and economic legacies of war shape contemporary gendered dynamics and experiences of post-war development in Kayah state. In conclusion, the empirical and theoretical significance of these findings are considered.

\section{Ceasefire, Illiberal Peacebuilding and Post-War Development in Kayah State}

Kayah state is the smallest of Myanmar's ethnic minority states, yet has a very complex history of armed conflict, which began after independence from the British in 1948. Conflict across the state continued more or less uninterrupted until the early 2000s. The largest of the non-state armed groups in the state is the Karenni 
National Progressive Party (KNPP). Diverging political ideologies and in-fighting led to a split within the KNPP in the 1970s, resulting in the formation of the Karenni Nationalities People's Liberation Front (KNPLF), followed by the Kayan National Guard (KNG), the Kayan New Land Party (KNLP), the Karenni National Democratic Party (KNDP) and the Karenni National Peace and Development Party (KNPDP) in the mid-to late 1990s, and the Karenni National Solidarity Organization (KNSO) in early 2000s. Several of these smaller fractions agreed to ceasefires with the military regime in the 1990s, pushing the KNPP, suddenly isolated, into a short-lived ceasefire in 1995 (Kramer et al. 2018). In the wake of the break-down of the talks, which lasted only three months, the state military under the stewardship of the State Peace and Development Council (SPDC) extended their infamous "four-cuts" strategy into most, if not all, areas of the state in their attempt to quell resistance. This had catastrophic consequences for the local population regardless of ethnic minority belonging. ${ }^{2}$ Thousands of civilians were forcibly displaced after their villages were burned down by the Myanmar military (Amnesty International 1999).

The ceasefires agreed between the SPDC government and the smaller armed groups in the 1990s spurred a growth of informal economies, including black-market logging, mining, and, to a lesser extent, opium production (see Meehan 2015; Jones 2016; Woods 2016a, b). While the KNPP did not agree to a formal ceasefire again until 2012 under the new Thein Sein government, existing ceasefire groups in the state transformed into so-called Border Guard Forces or government-backed pyithusit (a local militia closely aligned with the State military) after the 2008 Constitution took effect (Kramer et al. 2018; Buchanan 2016). Development projects initiated after this, such as logging and mining projects, road network expansion and dam constructions, while largely controlled by the government or associated military officials, have formed the basis of the deals struck with ceasefire groups (Mangan 2018). Problematically, and as we will elaborate on in more detail further below, these economic initiatives have not benefited the local population, who in many cases have been cut off from resources and land (see Land in Our Hands Network 2015; Karenni Social Development Center 2016; The Burma Consortium 2014).

In scholarly analyses, these ceasefire agreements underpinned by economic incentives have been studied as a predatory form of "ceasefire capitalism" that constitutes "war by other means" (Woods 2011, 2016a) and as the deployment of development as counterinsurgency (Brenner 2017; Goodhand 2013). In Myanmar, the extension of state authority into previously rebel-held territories, using development as one of its main vehicles, has to a large extent been perceived as threatening, given that people in minority-populated border areas often have had no other experiences of the Myanmar state than the coercive power of the State military forces (South 2018; Burke et al. 2017). Government strategies for development in post-war areas of the country corresponds closely to theoretical accounts of illiberal peacebuilding: domestically-driven peacebuilding that deviates from liberal norms (Waldorf et al. 2020). According to Soares De Oliveira, illiberal peacebuilding is:

\footnotetext{
${ }^{2}$ Multiple ethnic minority groups live in Kayah state. We interviewed women and men who self-identified as Kayah, Kayan, Kayaw, Shan and Karen.
} 
a process of post-war reconstruction managed by local elites in defiance of liberal precepts of civil liberties, the rule of law, the expansion of economic freedoms and poverty alleviation, with a view to constructing a hegemonic order and an elite stranglehold over the political economy (Soares De Oliveira 2011, p. 288).

Arguably, this definition provides a strikingly accurate description of the processes of economic and political transformation that are taking place in Myanmar's conflict-affected borderland regions in general, and in Kayah state in particular.

Today, Kayah state remains predominantly rural, with most people making a living from subsistence and informal agriculture. However, there has been a rise in contract farming across the state (Cartmell 2019). Poverty is prevalent, with many households lacking access to even basic services. About one-third of the population lives in poverty; half is reportedly unemployed (IHLCA Project Technical Unit 2010). Although the state is rich in natural resources, such as hydropower, tin and tungsten, the majority of the population has not, until now benefitted from investments and development projects (Kramer et al. 2018; Molo Women Mining Watch Network 2012). For example, despite the presence of dams, $74 \%$ of households use firewood for cooking, and a little less than half of all households surveyed use electricity for lightning (Myanmar Department of Population 2015). Economic reforms in the state, planned or under way, are focused on developing infrastructure and natural resource management, and on increasing tourism and border trade with Thailand (Mercy Corps 2013; UNDP 2014; "Kayah State Economic Overview" 2014). While some recent progress has been made with regards to provisions of social services, these investments have not been enough to meet the extensive needs of people living in rural areas of the state (UNDP 2014). Thus, over time, Kayah state has received little in the way of development assistance and social services provided by the central government, resulting in inequality and insecurity among rural populations (Kramer et al. 2018; Buchanan et al. 2013; Karenni Development Research Group 2006).

Following elections in 2010, the new semi-civilian government led by Thein Sein initiated an ambitious agenda for political and economic liberalization, and renewed peace talks with a number of ethnic armed organizations (EAOs), culminating in a National Ceasefire Agreement (NCA) signed by eight EAOs in 2015 (Ardeth Maung Thawnghmung 2017). These recent political and economic reforms have resulted in an expansion of foreign and private investments, driven by a market-led liberalization process pushing land-intensive large-scale infrastructure projects (such as dams, mines, highways) and agribusiness expansion (Scurrah et al. 2015; Mangan 2018; Republic of the Union of Myanmar 2012), without comparable or sufficient investments in public goods (Myanmar Department of Population 2018). These developments, facilitated by new investment laws and land policies which have made it easier for private and foreign entities to acquire communal land (Ferguson 2014; Woods 2014) have affected women in particular ways. Women have less formal access to land, yet mostly work on and with land: studies show that over $70 \%$ of economically active women are employed within the agricultural sector. Startlingly, the vast majority of these women, over $90 \%$, are working in the informal economy, 
with little or no job security or protection (Japan International Cooperation Agency 2016; Myanmar Department of Population 2017). Close to a third of all households in Kayah state are headed by women, as men have left the area due to conflict and a lack of socio-economic opportunities (Myanmar Department of Population 2015).

As a recent World Bank report notes, "most measures of inequality have risen over the reform period... as individuals with better education and more capital to invest have benefitted more from the early liberalizations and reforms"(World Bank 2017). This suggests that socio-economic opportunities associated with recent investment have, to a large extent, benefitted existing power holders rather than lowskilled rural agricultural workers clustered in the informal economy, a sector which remains dominated by women (Ford et al. 2016; International Labour Organization 2018; Woods 2016a). Numbers from the most recent Labor Force Survey are reflective of this: women are more likely to be economically inactive due to household and other reproductive responsibilities; to earn less when they do work; and to primarily be employed within the informal economy-which, as noted by the World Bank, has increased in the post-war period (International Labour Organization 2015; World Bank 2017; also see Japan International Cooperation Agency 2016). Women's participation in the informal and the domestic economy is directly related to Myanmar's multiple armed conflicts which have resulted in, among other things, an underinvestment in welfare provisioning and a lack of educational and formal job opportunities for women from ethnic minority areas (Belak 2002; Hedström 2016).

While there has been little outright fighting in the past fifteen years, the security and political situation in Kayah is still fragile (Molo Women Mining Watch Network 2012; Kramer et al. 2018; Agatha Ma and Kusakabe 2015). Most of the communities living in the state have been subjected to decades of war, resulting in high levels of displacement and widespread human insecurity. Close to 25,000 people still remain displaced within the state, with a further 10,000 registered as refugees in neighboring Thailand (Kramer et al. 2018; Cartmell 2019; The Border Consortium 2014). Some townships in Kayah state are still under dual administration, with local armed groups partly responsible for local governance and social provisioning in the areas under their authority. Further, recent development projects have caused skirmishes between KNPP and the State military forces, leading the KNPP to demand that government plans for new roads and hydropower projects must be halted until real political progress is made in the peace process (Karenni Development Research Group 2006; Kramer et al. 2018). For example, in 2012, fighting erupted after the State military brought in troops to work on road development near the Maw Chi mines, and in 2017 four KNPP soldiers were shot dead after allegedly finding "illegal timber" in a State military truck. Thus, while development in Myanmar is frequently represented as a path to peace, development in the wake of armed conflict has also spurred continued conflict, insecurity and violence. Indeed, as expressed by a technical advisor, working closely with the KNPP:

The projects [the government] would like to do, for example building roads and bridges, will be in the conflict areas. So, you know, the skepticism is that [this] will allow for rapid militarisation in these areas, which are areas where the Karenni population lives or used to live before they had to flee, and one 
day will [return to]. But if it is militarized by the [State military] this will be a problem. And also militarily speaking, some of these areas are strategically important for KNPP. ${ }^{3}$

The concerns expressed here are well in line with scholarly accounts of post-war development in Myanmar (and beyond) as war by other means; of economic counterinsurgency; and of illiberal peacebuilding that prioritizes regime security and control over accountability, human rights, and social inclusion (Brenner 2017; Woods 2016a, b; Waldorf et al. 2020). However, critical analyses of Myanmar's post-war economic reforms and development processes, as well as the emerging literature on illiberal peacebuilding, remain largely gender blind. More knowledge about the gendered dynamics and effects of these processes is needed for a fuller understanding of the political economy of post-war development in Myanmar and beyond. Next, we outline an analytical framework well suited to this task.

\section{Exploring Gendered Dynamics of Post-War Development: A Feminist Political Economy Approach}

Feminist scholarship on development and post-conflict reconstruction and reforms offers useful analytical resources to make sense of the gendered nature and effects of processes of political, social and economic transformation (True et al. 2017; Elias and Gunawardana 2013). These fields highlight how women's material and physical vulnerability and poverty are shaped by broader gendered political economic processes which obscure their reproductive and informal labor while limiting investments in state welfare (LeBaron 2010; Mies 2014; Martin De Almagro and Ryan 2019). This perspective makes it clear that processes of change are always shaped by, and in turn shape, gendered relations of power, making it possible to see how recent reforms in Myanmar have deepened, rather than alleviated, gendered inequalities by increasing women's caretaking responsibilities at the same time as their access to communal land and formal work is being constrained. Thus, a feminist political economy analysis enables us to explore the effects of recent reforms on rural, ethnic minority women living in conflict-affected border areas, such as Kayah state.

\section{Gendered Division of Labor}

Feminist research in political economy stresses the construction of a gendered division of labor, through a focus on women's responsibilities for social reproduction (Federici 2004; Mies 2014; Hoskyns and Rai 2007). This research pays attention to the economic and political processes that "simultaneously organises these gendered relations and extends them far beyond the market" (Bakker 2007). In this article we draw on this wealth of feminist scholarship to define social reproduction as the

\footnotetext{
3 Interview with technical advisor to KNPP, Chiang Mai, Thailand, Nov 72018.
} 
everyday activities involved in maintaining and reproducing life, labor, and love. This includes caretaking in the family, social provisioning in the community, generational transmission of knowledge and cultures, and the physical reproduction of families, communities, and the labor force itself, through childbirth. These relations of care and reproduction, present during armed conflict and post-war situations, are not neutral but "imbued with the potential of dominance, exploitation, and even direct violence" (Vaittinen et al. 2019).

This literature emphasizes how governments regulate this gendered division of labor through polices and laws relating to, inter alia, family life, taxation policies, the household, and other institutions. The cumulative effects of these privilege a specific gender order in which women are assigned the responsibility of care in the home, while men are situated as the heads of households and main actors in the economic sphere (Peterson 2002, 2010). In relation to post-war development and economic restructuring, feminist scholars in political economy highlight how women's reproductive work underpins, indeed even makes possible, capitalist and neoliberal development (True et al. 2017; True 2012). Examining how processes of economic transitions are reliant on women and other marginalized groups to "pick up the slack" for what the state should provide (in terms of welfare provisioning through devalued and/or unpaid feminized work), they illustrate how social reproduction, while not accounted for in official statistics, "are central to the production and reproduction of life" (Elias and Rai 2015). Tracing the structural links between transitional economies and the household, they suggest that gendered norms and relations shape, and limit, women's access to resources, authority, and power at "various sites and scales" in economic restructuring processes (Elias and Rai 2015). In our analysis, this research helps us draw attention to how gendered divisions of labor produce different gendered effects and experiences of development through separation between social reproductive and productive work, and between informal and formal labor (Safri and Graham 2010; Rai et al. 2014; Elias and Louth 2016).

\section{Formal and Informal Labor}

Another key theme in our analysis is the co-constitution of formal and informal labor. Although definitions may blur, in this paper we draw on the International Labour Organization to define informal employment as work where the employer does not contribute to social security, and the employee does not have access to a labor contract, paid annual leave, and/or paid sick leave (Interrnational Labour Organization 2018). This also includes self-employed persons, such as unpaid family workers, and those involved in domestic and social reproductive work, which in Myanmar is work primarily undertaken by women (Myanmar Department of Population 2017).

Feminist research in political economy has sought to unpack assumptions that differentiate between informal and formal work by highlighting the significant role that women play in subsistence economies, social reproduction, and other forms of informal and largely invisible labor (Fodor and Kispeter 2014; Elson 1999; Sassen 2000). This literature argues that the conceptualization of the market purely in terms of "productivity" conceals the ways in which women's informal labor underpins 
wider market reform. In doing so, it obscures the gendered implications of economic restructuring processes (Elias 2017; Nordstrom 1999; Martin De Almagro and Ryan 2019). In the absence of child and elderly care arrangements, and other forms of state welfare protection, women, already shouldering the responsibly for caretaking, "become a highly vulnerable group of informal, temporary workers" (Fodor and Kispeter 2014). Lacking opportunities to participate in the formal labor market due to extensive caretaking responsibilities, women are pushed into insecure work situations. The significance of locating women within these economic processes is evidenced in high levels of female poverty, extensive caretaking responsibilities, and poor working conditions for women. In other words, inequality and poverty are shaped by labor market structures that do not take into consideration women's informal labor, and by a limited system of state social protection (Elias 2017). For example, studies on women in export-oriented factory work show how the non-recognition of social reproduction creates a disposable (female) workforce: the underinvestment in state welfare programs pushes women into insecure work to provide for their families and communities, leading to insecurity and exhaustion (Gunawardana 2016). Notably, informal economies, including women's reproductive labor, peaks during post-war transitions, yet the artificial separation between formal and informal work obscures the value of women's labor, abstracting it from economic recovery and restructuring programs (see Martin De Almagro and Ryan 2019).

These insights are highly pertinent to understanding the situation in Myanmar's ceasefire areas, where the implementation of transitional economic recovery programs that prioritizes large scale infrastructure projects and land acquisitions risk further entrenching (rather than upsetting) gendered inequality and insecurity by undercutting women's income and survival sources. Instead, this creates a cheap and exploited work force (see Cornish 2017). Subsistence farming, women's unpaid reproductive labor, and the informal economy in opium, logging, bartering, and day labor is prevalent, and supposedly growing, according to recent World Bank reports (World Bank 2017), yet attention to these gendered effects are largely missing from economic reforms programs. This obscures the violence and insecurity endured by a feminized, and devalued, labor force (Nordstrom 2004, 2010; Sassen 2000), leading to gendered harm and depletion.

\section{Depletion}

The third concept we draw on in our analysis is depletion. Recent interventions in feminist political economy have sought to highlight the nexus between economic processes, social reproduction, and violence by employing the concept of depletion to render visible the emotional, material, and physical harm experienced by (some) individuals engaged in social reproductive and informal work. In this paper we understand depletion as occurring "when there is a critical gap between domestic, affective and reproductive outflows and inflows aimed at sustaining the wellbeing of people engaged in social reproduction" (Rai et al. 2014). 
The importance of depletion lies in its utility for identifying the harm done to individuals by the non-recognition or "naturalization" of social reproductive and other forms of unpaid or underpaid informal and insecure work (Rai et al. 2014). While this harm is embodied in the individual, enmeshed as she is within household or community relations, depletion may have broader consequences. For example, the care-work remittance-driven economy found in the Philippines are dependent on women's social reproductive labor, yet the depletion of women's bodies risk undermine "the well-being of households, communities and states" dependent on their work (Tanyag 2017). This research emphasizes that depletion emerges from unequal social structures that constrain women's access to socioeconomic opportunities, justice, and rights (True 2012). A focus on depletion helps us analyze women's experiences of recent reforms in Kayah state, where a degree of stability has enabled new processes of economic development, at the same time as people's lives remain shaped by persistent conflict dynamics and unresolved grievances in particular gendered ways, causing vulnerability as well as trauma.

Thus, feminist scholarship in political economy emphasizes the co-constitutive relationship between gendered relations of power, economic reforms, and informal and reproductive labor. Honing in on this nexus allows us to trace the gendered dynamics and effects of economic development in Kayah state on women's material, physical and emotional wellbeing. By doing so, we add new insights on how the post-war context shape gendered dynamics of development in particular ways.

\section{Materials and Methods}

In order to investigate the gendered dynamics of development in ceasefire areas in Myanmar this article focuses on the experiences of women living in Kayah state. Depending on ethnicity, kinship and class, women in Kayah state have experienced the gendered effects of development polices in different ways, and at different times. However, as we are specifically concerned with development in the wake of armed conflict, we focus in this article on women living in rural and conflict-affected areas of the state.

The article draws on fieldwork carried out by one of the authors in Chiang Mai, Thailand, and in Kayah state, Myanmar in November 2018. The bulk of the material consists of semi-structured interviews with women and men active in civil society organizations and armed groups, as well as focus group interviews and participant observation with female poppy farmers, women working in mining, and female farmers. The interviews in Kayah were conducted with the invaluable help of a local research assistant, Zin Mar Phyo. ${ }^{4}$ To follow up on some of the themes identified in these initial interviews, additional interviews with five women were carried out in February 2019 by the research assistant. In total, we interviewed forty-one people: 32 women, and 9 men. ${ }^{5}$ The women interviewed were of various ages- the

\footnotetext{
${ }^{4}$ Many thanks to Zin Mar Phyo for her excellent research assistance and photography skills.

5 A list of interviews can be found in Appendix.
} 
youngest woman interviewed was in her 20s and the oldest in her $80 \mathrm{~s}$ - but most women were between 30 and 70 years of age. Several of the women interviewed had had no schooling and were illiterate, but most had attended at least a few years of school. Married or widowed women had between two and ten children each. All had experienced severe trauma and insecurity related to both armed conflict and postwar development processes.

The three principal areas of relevance for this research include remote rural villages located in Hpruso Township, Eastern Kayah state; Hpasaung Townwhip, Southern Kayah state; and Pekon Township, Southern Shan state. Civilians living in these areas have been subject to widespread human rights violations, with at least two of the areas designated "black zones" during the height of armed conflict in the 1970s and 1990s. Black zones were areas labelled by the State military as "free fire zones", with villagers assumed to be rebel-sympathizers. Women we spoke to in Hpruso Township were forced to leave their homes in a relocation program designed by the regime in 1996, in which upwards of 30,000 civilians moved from their homes to live in sites under the control of military authorities (Amnesty International 1999). The women we interviewed in Hpasaung and Pekon had not moved to these relocation camps, but had instead attempted to stay near their villages, opting to hide in the jungle as necessitated by State military troop movements.

Because of the cumulative traumatic experiences of the majority of our respondents, we carefully developed a research protocol informed by feminist ethics and designed to minimize possible negative consequences for the research participants (Ackerly and True 2010; Brooten and Metro 2014; Hedström 2018). Paying attention to positionality, power, and relationship, we asked for informed consent ahead of, during, as well as after the interview, emphasizing to our respondents that they were ultimately in control of the interview, meaning that they could choose to terminate the interview altogether at any moment in time, and only answer questions if they felt comfortable doing so. We purposefully did not ask for information about traumatic events but kept the questions broad, and worked in close collaborations with a women's organization that is well grounded in the communities we visited. Access to the interviewees was obtained via this local organization, at which one of the authors had previously worked. If and when respondents showed signs of trauma (such as crying) we explained that while we are here to listen to anything they want to tell us, we can take a break at any moment of their choosing, or come back to the interview at another time. The research assistant, mentioned above, helped facilitate and organize these interviews and, when necessary, provide translation from local languages to English. She also helped design the research protocol to ensure the ethical standards we strived for were applicable locally. To triangulate the findings from these interviews, this article also draws on a wide range of materials published by civil society and research institutes analyzing development and ceasefire dynamics in Myanmar. 


\section{Gendered Dynamics of Development in Kayah State}

As described above, armed conflict and ceasefire deals relying on economic incentives have spurred the growth of informal economies in Myanmar over several decades. A degree of stability in ceasefire areas has facilitated state-led development efforts focused on large-scale infrastructure and energy projects, as well as extractive industries. However, investments in welfare and social provisioning have lagged far behind, in particular in rural, conflict-affected, minority-dominated border areas such as Kayah state. The analysis sections below outline our empirical findings about the gendered effects of these larger economic and political processes. In turn, we describe how women's experiences of development in Myanmar are shaped by unequal gendered divisions of labor leading to depletion; how women's informal labor underpins economic reforms; and how access to and ownership of land in the context of economic restructuring is gendered and contributes to insecurity for women.

\section{Gendered Divisions of Labor and Depletion}

Development processes, including recent efforts made at consolidating the informal economy in the wake of armed conflict in Myanmar, are implemented in a complex - and largely unequal-gendered setting. As the 2014 census reveals, a majority of women in Kayah state are not engaged in the formal labor force, suggesting that women are instead shouldering extensive social reproductive burdens in sustaining their household needs. This includes unpaid and largely unacknowledged labor in the community and the household, such as childrearing, cooking, and cleaning. Social reproductive work is extensive and time-consuming work, especially so among poor and vulnerable groups where the negative effects of caretaking are amplified by a lack of material opportunities (True 2012, p. 163). As we develop in more detail below, major infrastructural developments in rural areas of the state have cut communities of from traditional livelihoods, pushed men into migration, and constrained women's opportunities to take advantage of jobs in the formal sector by increasing their caretaking responsibilities (see Cornish and Ramsay 2018; Cornish 2017). It is against this background that Myanmar's economic development has to be assessed.

In Kayah state, our interviews show that generations of conflict and under-development in rural communities have resulted in a stark division of labor. The time women spend on social reproductive work limits the time they spend on accessing education or paid employment. Heavy labor, like farming and water collection, exposes them to physical insecurities, including prolapsed uterus and sexual harassment (Ackerly and Attanasi 2009). The women we interviewed collected water and firewood, and were in many cases responsible for subsistence farming on land located a couple of hours walk from their houses. During the conflict years, the women we met all shared experiences of having to shoulder full responsibility for their family's survival, as male family members either went into hiding or joined the uprising against the state military. In some villages, women had to feed both the rebel army and the state armed forces. This multiplied the pressure on the women to 
find ways to meet basic needs, for themselves as well as for the community at large. One Kayah woman living in a village outside the state capital Loikaw described her gendered responsibilities during the conflict years in the following way:

All the husbands, they hide in the jungle, and during that time, all the women remain in the village. So they are the ones who are responsible for everything. When the Burmese soldiers come, the women have to cook, and give them food, and everything they want. We face the threats. And also most of the [rebel] soldiers, they are also depending on me, for example if they need food, or other things, or want to hide the guns... But then the Burmese took everything, the house and all properties, like the barn and also the cows, and forced us to leave. ${ }^{6}$

Most of the women we spoke to described feelings of exhaustion, fear, and stress, rooted in a gendered division of war-time labor that positioned women as responsible for their family's survival. ${ }^{7}$ The loss of farmlands, houses, water buffalos, and hens, made this at times an impossible task, putting tremendous pressure on women's mental and physical health. These feelings of exhaustion, fear, and stress emerged both from conflict-related trauma and the at times seemingly impossible task of keeping their families afloat without the extra income generated by a husband, and without access to technical skills and know-how (including basic literacy skills) that could propel these women into higher paid jobs and access opportunities in the formal sector. Several women we interviewed described this trauma as physical, reporting aches and pains in their heads and hearts.

I have no medicine to cure my feelings. I want medicine for my feelings. [But] even when I drink medicine, it cannot cure my fear, that disease. That hurt that comes from my past, I cannot cure that, I need medicine for that. ${ }^{8}$

In this and other quotes, women's accounts of their responsibilities for social reproductive work were animated by the depletion this entailed. The reverberation of war-time depletion through social reproduction is felt today, as women's gendered responsibilities to secure necessities for themselves and their families restricted their own possibilities to gain an education or access secure employment. This illustrates how material inequalities, stemming from a gendered division of war time labor, restrict rural women's abilities to benefit from recent economic reforms. The woman quoted above does not read or write, or indeed speak Burmese. Just across the state in Pekon, a Kayan poppy farmer we interviewed shared similar experiences:

My whole life I lived here, I never went to school, and don't even understand Burmese, don't know how to read and write. My mother asked me to take care of the cows and buffalos, so I did that (Photo 1). ${ }^{9}$

\footnotetext{
${ }^{6}$ Interview 12 (with female farmer, 25/11 2018, Kayah state).

7 For example, interview 13 (with female farmer, 25/11 2018, Kayah state), interview 16 (with two female poppy farmers, 26/11 2018, Shan state, and interview 17 (with two female miners, 27/11 2018, Kayah state).

${ }^{8}$ Interview 12 (with female farmer, 25/11 2018, Kayah state).

${ }^{9}$ Interview 16 (with female poppy farmer, 26/11 2018, Southern Shan state).
} 


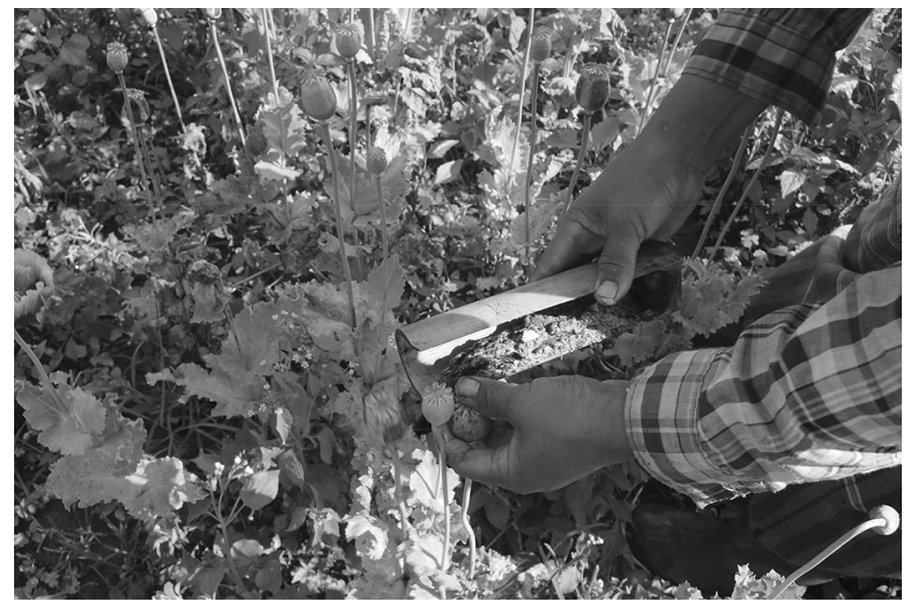

Photo 1 Kayan poppy farmer harvesting raw opium. Photo by Zin Mar Phyo

Significantly, neither of the two women quoted above knew much about Myanmar's recent reforms. Unable to speak or read Burmese, they were unsure as to what changes had taken place in the central government, or when. They knew the fighting had been reduced, had observed a slight increase in the quality of roads, but did not know when the last election had taken place. One of the women thought it happened in the 1990s, the other one did not know what an election was. This is also illustrative of the exclusion of women from township and village tract decision-making committees in the state, including those informing the planning and implementation of rural development funds A recent UNDP report found that close to $90 \%$ of women they surveyed had never been consulted to discuss village tract or ward development projects in Kayah state (UNDP 2014). It is important to pay attention to this, because although neither of the women above know much about the country's recent economic changes, both are affected by them, not least though the ways in which their informal labor underpins, indeed makes possible, broader economic changes in the country.

\section{Formal and Informal Labor}

Post-war gendered imbalances amplify women's workload within and outside the household. This may force women into seeking and accepting precarious forms of work within the informal sector (True 2012). Our research suggests that women's extensive reproductive responsibilities, when understood in relation to the under-investment of state social provisioning, have pushed women into unsafe and 
undervalued informal work, including poppy farming and mine waste cleaning. In Myanmar, as is common in many post-conflict states, the informal sector is the largest sector (World Bank 2017). This has in effect created a disposable and vulnerable labor force from which economic development can be built (see Martin De Almagro and Ryan 2019).

Most women we interviewed were engaged in underpaid day labor, alongside their subsistence farming and other reproductive duties. The women reported being paid less than men when engaging in day labor. This precarious nature of their work arguably strengthens the economy which benefits from their (gendered) vulnerability (see Gunawardana 2016; True 2012). This becomes apparent if we look at the lead and tungsten mines in southern Kayah state, which have provided the local Karen community with an income for generations. Only men can work inside the mines: when asked why, we were told that women's caretaking responsibilities means that women cannot go down inside the tunnels. ${ }^{10}$ Instead, women search the slag heap for small lead ores to clean and sell. Moreover, the area is under expansion, and we were told that Chinese companies, in addition to "crony companies" ${ }^{11}$ have moved into the region, selling off land and pushing the local community to sell their lead back to the company at a fixed, low, price (also see Kramer et al. 2018, p. 120). Many women in the area are widows, having lost their husbands due to the dangerous nature of the mining work.

The major challenge the women face in the area is when they become widows, because their husbands have died from lung disease...In Maw Chi area, especially in our village, there are hundreds of women who now live without a husband, because their husbands have died from lung disease... Women only work outside the mine, searching for small lead ores at the slag heap [because] women are not allowed to go and work inside the tunnel (Photo 2). ${ }^{12}$

Moreover, larger-scale investments projects in Kayah state, such as dams, have undercut women's access to their subsistence or traditional livelihoods, forcing them to either work in exchange for low day-wages on land they previously considered theirs, or to pay for access their farmland (Cornish 2017). For example, a group of Kayan female farmers we met had been forcibly relocated due the building of the Upper Paung Laung Dam. Their new area had no farming possibilities, pushing the women to return to areas of their land not yet flooded by the dam. However, to reach these areas, they have to pay the dam company 4000 Kyat (about 3 USD). The lack of adequate compensation, including new farming lands, have resulted in a worsening of livelihood opportunities. These findings are also corroborated in other

\footnotetext{
10 Interview 17 (with two female miners, 27/11 2018, Kayah state).

11 Crony companies, or cronyism, is used in Myanmar to refer to companies well placed to leverage from economic development and investments, such as those owned by the military, resulting in elite/military capture of the economy. See Ford et al. 2016; Woods 2016a).

12 Interview 17 (with two female miners, 27/11 2018, Kayah state).
} 


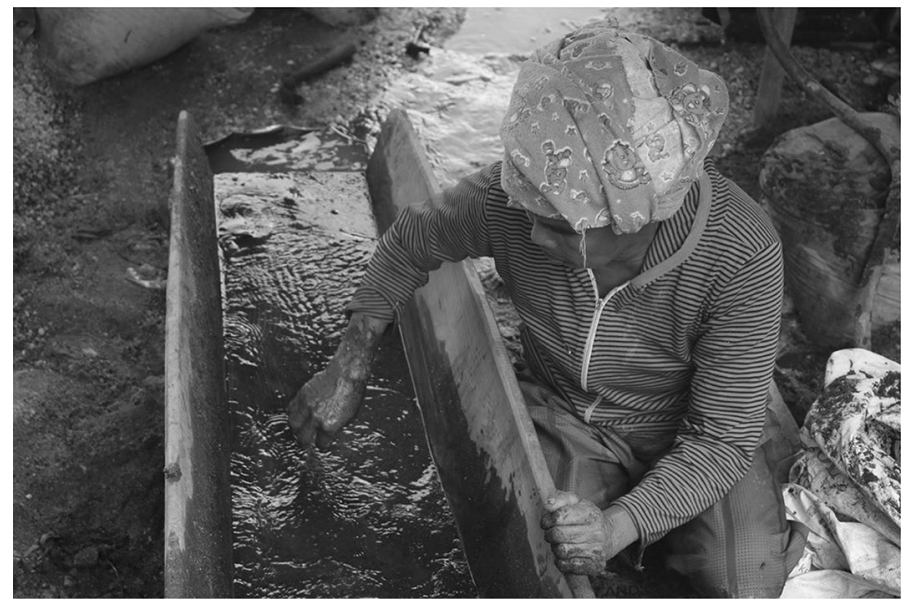

Photo 2 Widow searching the slag heap for small lead ores to clean and sell in Maw Chi. Photo by Zin Mar Phyo

reporting from this area, which found that the dire economic prospects have had specific gendered effects: while women stay behind to ensure the wellbeing of children and the elderly, often engaging in day-labor, men take up jobs abroad or in cities (Cornish and Ramsay 2018; Cornish 2017, 2018).

This division of labor is not necessarily seen by the state as detrimental to economic development policies. To the extent that they are considered at all, women's flexible and underpaid or unpaid labor is most likely viewed as competitive whilst their caretaking roles fills the gap in welfare provision, thus limiting the urgency of the state to provide welfare, including basic infrastructure, for its citizens (Bakker and Gill 2003; LeBaron 2010). In Kayah state this gap is extensive. Among the women we interviewed, access to electricity and water supply is limited. While roads networks have been improved, most of the villages visited for this research were only accessible via dirt roads, making them, if not impassable, then at least hard and treacherous to travel on, especially during the rainy season. As one woman succinctly summarized it: "the most important need is water, the second is health, the third is the road. Even though the road has improved [after 2011], in the rainy season, we cannot travel. No way."13

As a result, the time women spend on undertaking social reproductive work eats up the time they can spend on productive work. For example, in one village we visited, the nearest well was a twenty-minute walk down a hill, which required ample physical strength on behalf of the women to both collect the water and carry it back up the hill to the village. The well itself was located inside a cave, which meant that the women had to climb into the mouth of the cave and then down and through a narrow passage, which lacked both light and sufficient oxygen. Miscarriages were reported to take place after visits to the tunnel, suggesting that in addition to

13 Interview 14 (with female farmer, 25/11 2018, Kayah state). 
restricting the time available to work in the formal economy, the burden of reproductive duties also results in bodily harm. In fact, no women we spoke to had ever received medical assistance from a trained doctor or nurse in a hospital, due to the absence of road and hospital infrastructure, the paucity of time resulting from their caretaking duties, and a lack of Burmese language skills. Instead, child births and illnesses are dealt with at home, the responsibility of the women in the village. In other words, rural women's extensive caretaking responsibilities, when understood in relation to a lack of social provision and state welfare, exposes them to insecurity and violence.

The Union government, in cooperation with local armed groups and the state military, are complicit in creating this vulnerable - and feminized-workforce through their extensive involvement in and control over development projects in the state. For example, the mining industry, discussed above, is controlled by a State military conglomerate, the Union of Myanmar Economic Holdings Limited, with close links to the central government. The KNSO, and to a certain extent, the KNPLF and KNPP, control smaller parts of this industry. The Upper Paung Laung Dam, also discussed above, is owned by the government, while the KNPLF is involved in the development of the state's nascent tourism industry (Kramer et al. 2018; Cornish 2017). Women's material and physical vulnerability and poverty are shaped by their absence from these broader economic processes: the leadership of these armed groups are largely, if not completely, androcentric, suggesting that male capture of economic development initiatives renders women's informal and reproductive labor invisible. In this context, women's restricted access to formal land rights positions them, as well as the community relaying on their labor, as especially vulnerable to poverty, dispossession and discrimination.

\section{Gender and Land}

Against this background of a gendered division of wartime as well as post-war labor visible both within the individual household and across the communities surveyed, women's restricted access to formal land rights reinforces their vulnerability. Local groups report that, since 2011, more than 50,000 acres of land have been confiscated by State military forces, government agencies, and individual businessmen (Karenni Social Development Center 2016; Htoe Myar 2016). As land is used customarily, many people do not have the legal documents identifying them as the owners of the land; in addition, women are typically not recognized as head of households. This is problematic because land registration documents are often issued in the name of a (male) head of the household, and local administrators will not allow multiple names on the form (Faxon 2014, 2017). This makes women especially vulnerable to land grabbing and relocation, as their claims to land cannot be formally verified. Their opportunities to stop their land from being taken, or receive compensation when they are relocated from it, are small. This is reflective of wider gendered dynamics present in Kayah state where almost 30 cent of the rural female population is illiterate, and no women have been elected to the state-level government or to high decision-making positions at the township level (Myanmar Department of Population 
2017; UNDP 2014). Rural women, with limited or no proficiency in Burmese, often lack the know-how and confidence needed to interpret and challenge legal decisions; in addition, gendered biases in law and in practice present additional obstacles, such as the absence of formal land claims upon collective land. In Kayah state, women we met who previously had access to land through indirect customary provisions had lost this access upon the death of their spouses; other had been left waiting for their formal land claims to be verified:

In terms of land ownership, we owned some pieces of land [customary land], which have been used [for farming, cultivation] by the family for many generations. However, we do not have legal documents to prove land ownership because the government have never issued any for us. Although we have requested the authorities to issue us the legal document regarding the land ownership our request is still pending. ${ }^{14}$

Recent land laws are increasing communities' vulnerability to land loss, as these are in effect legitimizing the move to bring agrarian areas under customary use under the control of the government (Faxon 2017; Woods 2014; Scurrah et al. 2015; Ferguson 2014). The rural communities we visited are dependent upon farming with all practicing shifting cultivation (taungya), making the government's move to appropriate lands used under this practice particularly worrisome. While work on land and gender in Myanmar shows that in some instances land has been successfully registered in a woman's name, among the women we interviewed, this was not the case. The absence of female ownership is rooted in widespread conceptions about and practices of male superiority (see Ikeya 2005, 2011), suggesting that a gendered division of labor within the household is constitutive of gendered inequalities in relation to the state and the formal economy. For example, one woman we interviewed recalled being forcibly moved from the site of a dam project in 2013. Only through persistent activism by civil society organizations did some families manage to secure compensation for the loss of land. However, as women are rarely recognized as the formal owners of land, compensation was not paid to women:

The local authorities do not even recognize the woman's name, just only the leader of the family. The leader is a man, so nothing for women [...] they have no more land to do cultivation, and $95 \%$ of people are farmers, now they have no land to survive. All of the area is flooded. So business people become bigger business. Poor people, they lose everything. ${ }^{15}$

For single women in particular, relocation can make survival seem almost impossible. Describing the desperation felt by women who have lost their land and their means of survival as a result of infrastructural projects, the woman quoted above relates a story of a pregnant woman in her community who committed suicide a few years ago: "she hung herself... after she lost everything, and did not have any

14 Interview 17 (with two female miners 27/11 2018, Kayah state).

15 Interview 3 (with two female activists 22/11 2018, Kayah state).

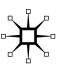




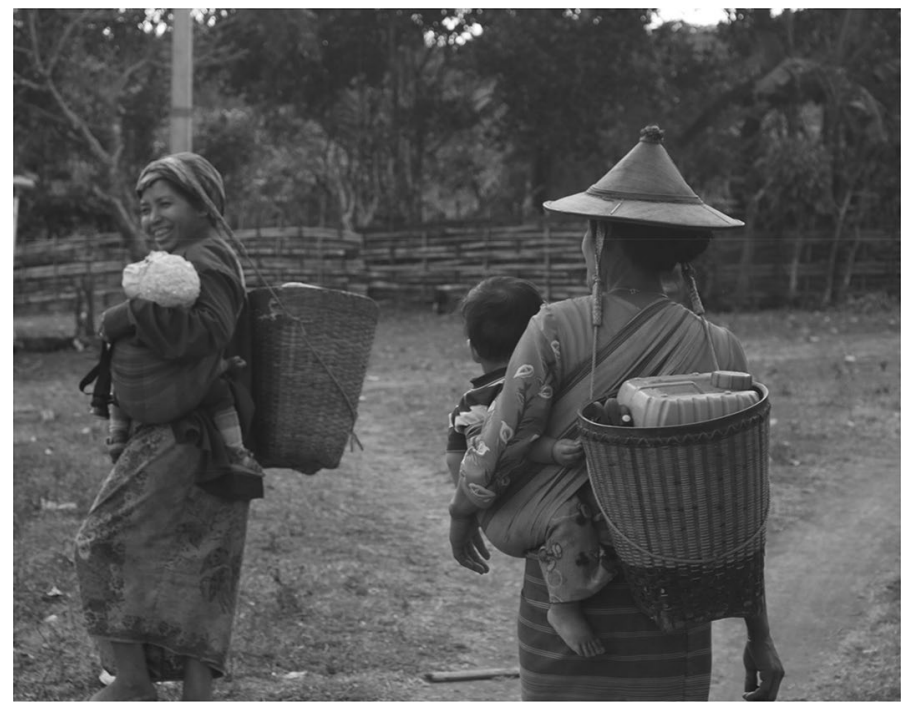

Photo 3 Kayah women collecting water from a cave. Photo by Zin Mar Phyo

ownership, she got depressed". ${ }^{16}$ As this example dramatically illustrates, when post-war development intersects with persistent gender inequalities, insecurity, suffering and even death results.

Moreover, the effects of farmland appropriation for development projects invariably take place within the context of persistent insecurity, often pushing men to migrate in search of new livelihood opportunities. Women will stay behind caring for children and other dependents, as this quote suggests:

If there is land grabbing because of development projects, then in that case, women are suffering more than men because if their lands are grabbed, men can move to another place, for their livelihood and their income. But women they cannot like men, because they have their children and their families and the other things (Photo 3$).{ }^{17}$

This illustrates how gendered expectations and responsibilities create material inequalities, shaping women's experiences of the economic transition currently underway. As we found in this and other interviews, women's participation in informal (day labor) and reproductive work (household, subsistence farming) interact to limit or structure their relationship to the formal market. The relationship between a gendered division of labor and economic reforms is rooted in perceptions about male leadership and ownership, and realized through large-scale investments and land acquisitions that leave women with few resources to improve their and their family's well-being. In interviews, women said they lacked the time, the health, or the

16 Interview 3 (with two female activists 22/11 2018, Kayah state).

17 Interview 6 (with two male activists, 23/11 2018, Kayah state). 
education required to resist land-grabbing practices. ${ }^{18}$ In other words, relations of gendered power are (re)produced at multiple sites - the home, the farm, the community - fueling cycles of gendered violence, exclusion, and depletion (see Elias and Rai 2015). While some women do resist, most are simply, and barely, surviving, wishing to stay out of political activities (see Agatha Ma and Kusakabe 2015). In this setting, new land laws, while a key pillar of the government's recent move to modernize and liberalize the Myanmar market (Republic of the Union of Myanmar 2012) are affecting women from ethnic minority communities in ways which risk heightening their vulnerability, rather than their resilience. Moreover, insufficient Burmese language skills, a lack of formal land rights, and extensive reproductive responsibilities has meant that rural women in particular are unable to benefit from trading, tourism, and large-scale agribusiness and natural resource management (see Agatha Ma and Kusakabe 2015; Cartmell 2019; Cornish and Ramsay 2018; Cornish 2017). Consequently, recent development initiatives and economic reforms shape, and are shaped by, gendered dynamics, pointing to the importance of exploring and understanding the relationship between development and gender in the wake of armed conflict.

\section{Conclusion}

In this article we have argued for the importance of paying analytical attention to the ways in which economic development processes implemented in Myanmar's transitional landscape intersect with existing gendered relations of power. Exploring women's experiences of economic development, we demonstrate how women's restricted access to formal land rights, coupled with their overrepresentation in the informal economy and their responsibility for social reproduction, positions them as especially vulnerable to poverty, dispossession, and violence. The absence of adequate state investments in social provisioning across the country exacerbates women's domestic burden, while the concentration of women in lower-paid, lower secure jobs intensifies their poverty. These cumulative gendered dynamics, when analyzed in relation to the central government's economic development initiatives, illustrate how post-war economic processes intersect with existing gendered relations of power to (re)produce forms of gendered insecurity, in particular among rural women living in ethnic minority areas like Kayah state, where levels of inequality and informality have risen during the transitional period. New land laws and large-scale infrastructural investments, while a key pillar of the government's recent move to modernize and liberalize the Myanmar market, heighten women's vulnerability and further entrench, rather than upset, exiting gender inequalities by undercutting women's income and survival sources. These findings demonstrate that gender-specific forms of abuse and insecurity in war does not disappear when the fighting stops, but

\footnotetext{
18 For example interviews Interview 12 (with female farmer, 25/11 2018, Kayah state), interview 13 (with female farmer, 25/11 2018, Kayah state), interview 16 (with two female poppy farmers, 26/11 2018, Shan state, and interview 17 (with two female miners, 27/11 2018, Kayah state).
} 
continues to shape women's everyday lives in the post-war for years or even decades to come. Through its strategies for post-war development, the Union government, in cooperation with local armed groups and the State military, is complicit in creating a vulnerable and marginalized work force of informal and often invisible women workers, furthering gendered insecurity, dispossession, and depletion.

Open Access This article is licensed under a Creative Commons Attribution 4.0 International License, which permits use, sharing, adaptation, distribution and reproduction in any medium or format, as long as you give appropriate credit to the original author(s) and the source, provide a link to the Creative Commons licence, and indicate if changes were made. The images or other third party material in this article are included in the article's Creative Commons licence, unless indicated otherwise in a credit line to the material. If material is not included in the article's Creative Commons licence and your intended use is not permitted by statutory regulation or exceeds the permitted use, you will need to obtain permission directly from the copyright holder. To view a copy of this licence, visit http://creativecommons.org/licen ses/by/4.0/.

\section{Appendix}

See Table 1.

Table 1 List of interviews

\begin{tabular}{|c|c|c|c|c|c|}
\hline $\begin{array}{l}\text { Interview } \\
\text { number }\end{array}$ & Location & Type of org./position & No of women & No of Men & Date 2018 \\
\hline 1 & Thailand & Armed org. & 0 & 1 & 07-Nov \\
\hline 2 & Thailand & Environmental org. & 1 & 0 & 12-Nov \\
\hline 3 & Kayah State & Women's org. & 2 & 0 & 22-Nov \\
\hline 4 & Kayah State & Farmer's union. & 2 & 3 & $22-\mathrm{Nov}$ \\
\hline 5 & Kayah State & Women's org. & 2 & 0 & 22-Nov \\
\hline 6 & Kayah State & Peace org. & 3 & 1 & 23-Nov \\
\hline 7 & Kayah State & Women's org. & 7 & 0 & 23-Nov \\
\hline 8 & Kayah State & Environmental org. & 0 & 2 & 23-Nov \\
\hline 9 & Kayah State & Armed org. & 1 & 0 & 24-Nov \\
\hline 10 & Kayah State & Women's org. & 1 & 0 & 24-Nov \\
\hline 11 & Kayah State & Refugee repatriation org. & 0 & 1 & $25-\mathrm{Nov}$ \\
\hline 12 & Kayah State & Farmer & 1 & 0 & $25-\mathrm{Nov}$ \\
\hline 13 & Kayah State & Farmer & 1 & 0 & $25-\mathrm{Nov}$ \\
\hline 14 & Kayah State & Farmer & 1 & 0 & $25-\mathrm{Nov}$ \\
\hline 15 & Kayah State & Women's org. & 1 & 0 & 25-Nov \\
\hline 16 & Shan State & Poppy farmers & 2 & 1 & 26-Nov \\
\hline 17 & Kayah State & Mining workers & 2 & 0 & 27-Nov \\
\hline 18 & Kayah State & Farmers & 5 & 0 & Feb 2019 \\
\hline
\end{tabular}




\section{References}

Ackerly, Brooke, and Katy Attanasi. 2009. Global Feminisms: Theory and Ethics for Studying Gendered Injustice*. New Political Science 31 (4): 543-555.

Ackerly, Brooke, and Jacqui True. 2010. Doing Feminist Research in Political and Social Sciences. London: Palgrave Macmillan.

Agatha Ma, and Kyoko Kusakabe. 2015. Gender Analysis of Fear and Mobility in the Context of Ethnic Conflict in Kayah State, Myanmar. Singapore Journal of Tropical Geography 36 (3): 1-15.

Amnesty International. 1999. Aftermath: Three Years of Dislocation in the Kayah State. London: Amnesty International.

Ardeth Maung Thawnghmung. 2017. Signs of Life in Myanmar's Nationwide Ceasefire Agreement? Finding a Way Forward. Critical Asian Studies 49 (3): 379-395.

Bakker, Isabella. 2007. Social Reproduction and the Constitution of a Gendered Political Economy. New Political Economy 12 (4): 541-556.

Bakker, Isabella, and Stephen Gill (eds.). 2003. Power, Production and Social Reproduction: Human In/ Security in the Global Political Economy., vol. 1. Basingstoke and New York: Palgrave Macmillan.

Belak, Brenda. 2002. Gathering Strength: Women from Burma on Their Rights. Chiang Mai: Images Asia.

Bello, Walden. 2018. Pradigm Trap: The Development Establishment's Embrace of Myanmar and How to Break Loose. Amsterdam: Transnational Institute.

Brenner, David. 2017. The Development-Insecurity Nexus: Geo-Economic Transformations and Violence in Myanmar. 1. LSE Global South Unit, London.

Brooten, Lisa, and Rosalie Metro. 2014. Thinking about Ethics in Burma Research. Journal of Burma Studies 18 (1): 1-22.

Buchanan, John. 2016. Militias in Myanmar. Yangon: Asia Foundation.

Buchanan, John, Tom Kramer, Kevin Woods, and Tom Kramer. 2013. Developing Disparity: Regional Investment in Burma's Borderlands. Amsterdam: Transnational Institute.

Burke, Adam, Nicola Williams, Patrick Barron, Kim Jolliffe, and Thomas Carr. 2017. The Contested Areas of Myanmar: Subnational Conflict, Aid, and Development. Yangon: The Asia Foundation.

Cartmell, Sam. 2019. Market Analysis for Rural Livelihoods in Kayah State. Mae Sot: The Border Consortium.

Cornish, Gillian. 2017. Women and Resettlement: A Case Study on Gender Aspects at the Upper Paunglaung Hydropower Dam. Yangon: SPECTRUM.

Cornish, Gillian. 2018. Women \& EIA Processes: A Case Study on Gender Aspects of EIAs in Four Myanmar Projects. Yangon: SPECTRUM.

Cornish, Gillian, and Rebekah Ramsay. 2018. Gender and Livelihoods in Myanmar after DevelopmentInduced Resettlement. Forced Migration Review 59 (October): 55-57.

Elias, Juanita. 2017. Governing Domestic Worker Migration in Southeast Asia: Public-Private Partnerships, Regulatory Grey Zones and the Household. Journal of Contemporary Asia 00 (00): 1-23.

Elias, Juanita, and Samanthi J. Gunawardana. 2013. The Global Political Economy of the Household in Asia. Basingstoke and New York: Palgrave Macmillan.

Elias, Juanita, and Jonathon Louth. 2016. Producing Migrant Domestic Work: Exploring the Everyday Political Economy of Malaysia's Maid Shortage. Globalizations 13 (6): 830-845.

Elias, Juanita, and Shirin Rai. 2015. The Everyday Gendered Political Economy of Violence. Politics \& Gender 11 (02): 424-429.

Elson, Diane. 1999. Labor Markets as Gendered Institutions: Equality, Efficiency and Empowerment Issues. World Development 27 (3): 611-627.

Enloe, Cynthia. 1990. Bananas, Beaches, and Bases: Making Feminist Sense of International Politics. Berkeley: University of California Press.

Faxon, Hilary Oliva. 2014. "Workshop Report: Women's Land Trainings in Lashio, Kyuakpadaung \& Mandalay." Yangon.

Faxon, Hilary Oliva. 2017. In the Law \& on the Land: Finding the Female Farmer in Myanmar's National Land Use Policy. Journal of Peasant Studies 44 (6): 1199-1216.

Federici, Silvia. 2004. Caliban and the Witch, 2014th ed. New York: Autonmedia.

Ferguson, Jane M. 2014. The Scramble for the Waste Lands: Tracking Colonial Legacies, Counterinsurgency and International Investment through the Lens of Land Laws in Burma/Myanmar. Singapore Journal of Tropical Geography 35 (3): 295-311. 
Fodor, Eva, and Erika Kispeter. 2014. Making the 'Reserve Army' Invisible: Lengthy Parental Leave and Women's Economic Marginalisation in Hungary. European Journal of Women's Studies 21 (4): 382-398.

Ford, Michele, Michael Gillan, and Htwe Htwe Thein. 2016. From Cronyism to Oligarchy? Privatisation and Business Elites in Myanmar. Journal of Contemporary Asia 46 (1): 18-41.

Gender Equality Network. 2015. Raising the Curtain: Cultural Norms, Social Practices and Gender Equality in Myanmar. Yangon: Gender Equality Network.

Gunawardana, Samanthi. 2016. 'To Finish, We Must Finish': Everyday Practices of Depletion in Sri Lankan Export-Processing Zones. Globalizations 13 (6): 861-875.

Goodhand, Jonathan. 2013. Contested Boundaries: NGOs and Civil-military Relations in Afghanistan. Central Asian Survey 32 (3): 287-305.

Hedström, Jenny. 2016. A Feminist Political Economy Analysis of Insecurity and Violence in Kachin State. In Conflict in Myanmar: War, Politics, Religion, ed. Nick Cheesman and Nicholas Farrelly, 67-90. Singapore: ISEAS -Yusof Ishak Institute.

Hedström, Jenny. 2017. The Political Economy of the Kachin Revolutionary Household. Pacific Review 30 (4): 581-595.

Hedström, Jenny. 2018. Confusion, Seduction, Failure: Emotions as Reflexive Knowledge in Conflict Settings. International Studies Review 21 (4): 662-677.

Hoskyns, Catherine, and Shirin Rai. 2007. Recasting the Global Political Economy: Counting Women's Unpaid Work. New Political Economy 12 (3): 37-41.

Htoe Myar. 2016. "NLD to Compile Land Grabbing List for Karenni State.” Burma News International, 2016. Accessed at: https://www.bnionline.net/en/2015-election/karenni-state/item/1402-nld-tocompile-land-grabbing-list-for-karenni-state.html.

IHLCA Project Technical Unit. 2010. Integrated Household Living Conditions Survey in Myanmar (2009-2010). Yangon: IHLCA Project Technical Unit.

Ikeya, Chie. 2005. The 'Traditional' High Status of Women in Burma: A Historical Reconsideration. Journal of Burma Studies 10 (1): 51-81.

Ikeya, Chie. 2011. Refiguring Women, Colonialism, and Modernity in Burma. Honolulu: University of Hawai'i Press.

International Labour Organization. 2015. Myanmar Labor Force, Child Labor and School to Work Transition Survey Report. Nay Pyi Taw: International Labour Organization.

International Labour Organization. 2018. Myanmar Decent Work Country Programme 2018-2021: A Tool To Advance Decent Work and Sustainable Development. Nay Pyi Taw: International Labour Organization.

Japan International Cooperation Agency. 2016. Data Collection Survey on Women's Economic Activities in Myanmar. Nay Pyi Taw: Japan International Cooperation Agency.

Jones, Lee. 2014. Explaining Myanmar's Regime Transition: The Periphery Is Central. Democratization 21 (5): 780-802.

Jones, Lee. 2016. Understanding Myanmar's Ceasefires: Geopolitics, Political Economy and StateBuilding. In War and Peace in the Borderlands of Myanmar The Kachin Ceasefire, 1994-2011, ed. Mandy Sadan, 95-113. Copenhagen: NIAS Press.

Karenni Development Research Group. 2006. Dammed by Burma's Generals: The Karenni Experience with Hydropower Development from Lawpita to the Salween. Chiang Mai: Karenni Development Research Group.

Karenni Social Development Center. 2016. "Military Confiscation of Karenni Ancestral Land in Karenni State, Burma." Nai Soi.

Kramer, Tom, Oliver Russell, and Martin Smith. 2018. From War to Peace in Kayah (Karenni) State: A Land at the Crossroads in Myanmar. Amsterdam: Transnational Institute.

Land in Our Hands Network. 2015. Destroying People's Lives: The Impact of Land Grabbing on communities in Myanmar. Yangon: Land in Our Hands Network.

LeBaron, Genevieve. 2010. The Political Economy of the Household: Neoliberal Restructuring, Enclosures, and Daily Life. Review of International Political Economy 17 (5): 889-912.

Mangan, Cormac. 2018. Private Enterprises in Fragile Situations: Myanmar. London: International Growth Centre.

Martin De Almagro, M., and Caitlin Ryan. 2019. Subverting Economic Empowerment: Towards Securities in Post-War Settings. European Journal of International Relations 25: 1059-1079.

Meehan, Patrick. 2015. Fortifying or Fragmenting the State? The Political Economy of the Opium/Heroin Trade in Shan State, Myanmar, 1988-2013. Critical Asian Studies 47 (2): 253-282. 
Mercy Corps. 2013. Kayah State Socio-Economic Analysis. Yangon: Mercy Corps.

Mi Thang Sorn Poine. 2018. Gendered Aspects of Access to Justice in Southern Mon State. Independent Journal of Burmese Scholarship 1 (2): 1-25.

Mies, Maria. 2014. Patriarchy and Accumulation on a World Scale: Women in the International Division of Labor. London: Zed Books.

Molo Women Mining Watch Network. 2012. Lost Paradise: Damaging Impact of Mawchi Tin Mines in Burma's Karenni State. Loikaw: Molo Women Mining Watch Network.

Myanmar Department of Population. 2015. "The 2014 Myanmar Population and Housing Census Kayah State." The 2014 Myanmar Population and Housing Census: Census Report Volume 3-B. Vol. 3. Nay Pyi Taw.

Myanmar Department of Population. 2017. "The 2014 Myanmar Population and Housing Census: Thematic Report on Gender Dimensions." Vol. 4-J. Nay Pyi Taw.

Myanmar Department of Population. 2018. "Multidimensional Welfare in Myanmar.” Nay Pyi Taw.

Nordstrom, Carolyn. 1999. Wars and Invisible Girls, Shadow Industries, and the Politics of Not- Knowing. International Feminist Journal of Politics 1 (1): 14-33.

Nordstrom, Carolyn. 2004. Shadows of War: Violence, Power, and International Profiteering in the Twenty-First Century. Los Angeles: University of California Press.

Nordstrom, Carolyn. 2010. Women, Economy, War. International Review of the Red Cross 92 (877): $161-176$.

Peterson, V.Spike. 2002. Rewriting (Global) Political Economy as Reproductive, Productive, and Virtual (Foucauldian) Economies. International Feminist Journal of Politics 4 (1): 1-30.

Peterson, V.Spike. 2010. Global Householding amid Global Crises. Politics \& Gender 6 (02): 271-281.

Rai, Shirin M., Catherine Hoskyns, and Dania Thomas. 2014. Depletion: The Costs of Social Reproduction. International Feminist Journal of Politics 16 (1): 86-105.

Republic of the Union of Myanmar. 2012. Framework for Economic and Social Reforms. Naypyitaw: Republic of the Union of Myanmar.

Safri, Maliha, and Julie Graham. 2010. "The Global Household: Toward a Feminist Postcapitalist International Political Economy. Signs: Journal of Women in Culture and Society 36 (1): 99-125.

Sassen, Saskia. 2000. Women's Burden: Counter-Geographies of Globalization and the Feminization of Survival. Journal of International Affairs 53 (2): 255-274.

Scurrah, Natalia, Philip Hirsch, and Kevin Woods. 2015. The Political Economy of Land Governance in Myanmar. Vientiane: Mekong Region Land Governance and University of Sydney.

Soares de Oliveira, Ricardo. 2011. Illiberal peacebuilding in Angola. Journal of Modern African Studies 49 (2): 287-314.

South, Ashley. 2018. "Hybrid Governance" and the Politics of Legitimacy in the Myanmar Peace Process. Journal of Contemporary Asia 48 (1): 50-66.

Tanyag, Maria. 2017. Invisible Labor, Invisible Bodies: How the Global Political Economy Affects Reproductive Freedom in the Philippines. International Feminist Journal of Politics 19 (1): 39-54.

ThaiBizMyanmar.Com. 2014. "Kayah State Economic Overview." 2014. ThaiBizMyanmar.Com.

The Border Consortium. 2014. Protection and Security Concerns in South East Burma/Myanmar. Bangkok and Yangon: The Border Consortium.

True, Jacqui. 2012. The Political Economy of Violence Against Women. Oxford: Oxford University Press.

True, Jacqui, Christine Chinkin, Madeleine Rees, Nela Porobic Isakovic, Gorana Mlinarevic, and Barbro Svedberg. 2017. A Feminist Perceptive on Post-Conflict Restructuring and Recovery: The Case of Bosnia and Herzegovina. Geneva: Women's International League for Peace and Freedom.

UNDP. 2014. The State of Local Governance: Trends in Kayah (Local Governance Mapping). Nay Pyi Taw: UNDP.

Vaittinen, Tiina, Amanda Donahoe, Rahel Kunz, Silja Bára Ómarsdóttir, and Sanam Roohi. 2019. Care as Everyday Peacebuilding. Peacebuilding 7 (2): 194-209.

Waldorf, L., G. McCarthy, C. Smith, and R. Venugopal. 2020. Illiberal Peacebuilding in Asia: A Comparative Overview. Conflict, Security and Development.

Waldorf, Lars et al. forthcoming. Illiberal Peacebuilding in Asia: a Comparative Overview. Conflict, Security \& Development.

Woods, Kevin. 2011. Ceasefire Capitalism: Military-Private Partnerships, Resource Concessions and Military-State Building in the Burma-China Borderlands. The Journal of Peasant Studies 38 (4): $747-770$.

Woods, Kevin. 2014. “A Political Anatomy of Land Grabs.” Myanmar Times, 2014. 
Woods, Kevin. 2016a. The Commercialisation of Counterinsurgency: Battlefield Enemies, Business Bedfellows in Kachin State, Burma. In War and Peace in the Borderlands of Myanmar The Kachin Ceasefire, 1994-2011, ed. Mandy Sadan. Copenhagen: NIAS Press.

Woods, Kevin. 2016b. "The Impact of Armed Conflict and Displacement on Land Rights in Kachin State." Yangon.

World Bank. 2017. Myanmar Economic Monitor: Capitalizing on Investment Opportunities. Nay Pyi Taw: World Bank.

Publisher's Note Springer Nature remains neutral with regard to jurisdictional claims in published maps and institutional affiliations. 